\title{
STRATEGI PENGEMBANGAN KENTANG (Solanum tuberosum L.) PADA KELOMPOK TANI PALINTANG JAYA, DESA CIPANJALU KECAMATAN CILENGKRANG, KABUPATEN BANDUNG
}

\author{
MILDA SELVIA, ENDAH DJUWENDAH \\ Fakultas Pertanian Universitas Padjadjaran, Jalan Raya Bandung - Sumedang KM 21 Sumedang, \\ 45363 \\ *Email: mildaselvia@yahoo.co.id
}

\begin{abstract}
ABSTRAK
Kelompok Tani Palintang Jaya merupakan satu-satunya kelompok tani yang mengikuti kegiatan diklat yang diselenggarakan oleh Balai Besar Pelatihan Pertanian Lembang (BBPP-Lembang), dimana dalam proses pengembangan usahatani kentang, kelompok tani tersebut masih mengalami kendala. Salah satu kendala yang dihadapinya adalah produktivitas usahatani kentang yang belum optimal. Penelitian ini bertujuan untuk mengetahui pendapatan yang diterima petani, menganalisis lingkungan internal dan eksternal, serta merumuskan alternatif dan prioritas strategi yang dapat dilakukan oleh Kelompok Tani Palintang Jaya. Faktor utama lingkungan internal dan eksternal diidentifikasi dengan menggunakan matriks IFE dan EFE. Hasil dari matriks IFE dan EFE digunakan untuk dasar penyusunan alternatif strategi dengan alat analisis matriks IE dan matriks SWOT. Hasil penelitian menunjukkan bahwa pendapatan usahatani bibit kentang dan usahatani kentang konsumsi menguntungkan untuk dijalankan. Matriks IFE menunjukkan bahwa terdapat delapan faktor kekuatan dan enam faktor kelemahan. Matriks EFE menunjukkan bahwa terdapat delapan faktor peluang dan empat faktor ancaman. Berdasarkan matriks IE, kelompok tani tersebut berada pada posisi menjaga dan mempertahankan (sel V). Berdasarkan analisis SWOT maka dihasilkan 6 alternatif strategi. Prioritas strategi yang dapat direkomendasikan untuk diterapkan terlebih dahulu oleh Kelompok Tani Palintang Jaya adalah meningkatkan kemampuan anggota dalam budidaya bibit kentang.
\end{abstract}

Kata kunci: Pendapatan, Strategi, Pengembangan, Usahatani, Kentang

\begin{abstract}
Palintang Jaya Farmer Group is the only one farmer group participating in the training activities organized by the Lembang Agricultural Training Center (BBPP-Lembang), when in the process of developing potato farming, the farmer group is still experiencing difficulties. One of the difficulties experienced by the farmer is the productivity of potato farming has not yet been optimal. This research aims to acknowledge the income received by the farmer, analyse the environment internally and externally, and to define the alternatives and strategies priority that can be done by the Palintang Jaya Farmer Group. The main factor of environment, internally and externally is identified by using IFE and EFE matrices. The results of the matrices are used as for the basis of preparing alternative strategies with IE matrix analysis tools and SWOT matrices. The result of the research shows that the income of potato seed farming and potato consumption farming is profitable to run. The IFE matrix shows that there are eight strength factors and six weakness factors. The EFE matrix shows that there are eight opportunity factors and four threat factors. According to IE matrix, the farmer group is in position to protect and maintain (cell V). Based on SWOT analysis, there are 6 alternative strategies. A strategic priority that is recommended to be implemented in advance by the Palintang Jaya Farmer Group is improving the capacity of its members in the field of potato seeds cultivation.
\end{abstract}

Keywords: Income, Strategy, Development, Farming, Potatoes 


\section{PENDAHULUAN}

Jawa Barat merupakan salah satu provinsi di Indonesia yang menjadikan kentang sebagai komoditas unggulan untuk dikembangkan. Jawa Barat merupakan provinsi kedua setelah Jawa Tengah yang menjadi sentra produksi kentang di Indonesia pada tahun 20122016 dengan selisih sebesar $0,94 \%$ atau selisih rata-rata produksi sebesar 11.251 ton (BPS, 2017). Produksi kentang di Jawa Barat mengalami peningkatan produksi kentang selama tiga tahun terakhir 2014-2016. Hal ini memperlihatkan bahwa Jawa Barat memiliki potensi dalam mengembangkan produksi kentang dari segi kondisi iklim dan prasyarat tumbuh tanaman kentang.

Kabupaten Bandung merupakan wilayah dengan kontribusi produksi kentang kedua terbesar di Jawa Barat setelah Kabupaten Garut, dengan rata-rata produksi kentang per tahun 104.816 ton. Namun, produksi kentang di Kabupaten Bandung pada tahun 2013-2015 mengalami penurunan. Hal ini menunjukkan perlu adanya pengembangan budidaya kentang di Kabupaten Bandung agar dapat menjadi sentra produksi. Terdapat 11 kecamatan di Kabupaten Bandung yang memiliki peluang dan berpotensi untuk pengembangan budidaya kentang, salah satunya adalah di Kecamatan Cilengkrang.

Kecamatan Cilengkrang merupakan wilayah kedua yang dengan rata-rata produktivitas kentang tertinggi setelah Kecamatan Kertasari. Kecamatan Cilengkrang terdiri atas 6 desa, namun hanya Desa Cipanjalu yang memproduksi tanaman kentang. Desa Cipanjalu terletak diketinggian $800 \mathrm{~m}$ sampai $1.400 \mathrm{mdpl}$ dengan jenis tanah latosol dimana $\mathrm{pH}$ tanah berkisar antara 5,0-7,0 (Tim Penyusun Program Desa Cipanjalu, 2018). Kondisi tersebut sesuai dengan prasyarat tumbuh kentang dimana Menurut Samandi (1997), ketinggian tempat yang ideal untuk menanam kentang adalah berkisar antara $1.000 \mathrm{~m}-1.300 \mathrm{mdpl}$, dan untuk daratan medium pada ketinggian 300m-700 mdpl dengan keadaan pH tanah yang sesuai untuk tanaman kentang bervariasi antara 5,0-7,0.

Kelompok Tani Palintang Jaya merupakan satu-satunya kelompok tani di Kecamatan Cilengkrang yang membudidayakan kentang dan mengikuti kegiatan diklat penguatan kapasitas dalam pendampingan bagi penyuluh pertanian yang diselenggarakan oleh Balai Besar Pelatihan Pertanian Lembang (BBPPLembang). Hasil dari diklat tersebut 
Kelompok Tani Palintang Jaya sudah dapat melakukan pembibitan secara mandiri meskipun terkadang kelompok tani tersebut masih membeli bibit kentang dari daerah lain.

Namun Kelompok Tani Palintang Jaya masih mengalami kendala dalam pengembangan usahatani kentang sehingga produktivitasnya belum optimal. Ketua Kelompok Tani Palintang Jaya (Bapak Iin) mengungkapkan bahwa produktivitas kentang di Kelompok Tani Palintang Jaya sebesar 20-25 ton/ha dengan menggunakan bibit granola. Padahal dengan menggunakan bibit granola produktivitas kentang bisa mencapai 30-35 ton/hektar (Setiadi, 2009). Hal ini disebabkan oleh penerapan teknik dan teknologi budidaya yang digunakan masih belum optimal, karena keterbatasan modal yang petani miliki sehingga teknologi yang digunakan oleh petani masih sangat sederhana yang berdampak pada rendahnya produktivitas dan kualitas kentang yang dihasilkan. Selain itu, keterbatasan varietas unggul dan rendahnya mutu benih yang digunakan mempengaruhi produktivitas dan kualitas kentang yang dihasilkan oleh petani.

Sebagian besar petani di Kelompok Tani Palintang Jaya membudidayakan kentang di lahan sewa milik perhutani dengan sistem Profit sharing. Hampir 80\% petani menyewa lahan perhutani dan 20\% petani membudidayakan kentang di lahan milik sendiri. Pihak Perhutani mengharuskan petani untuk menanam tanaman keras di lahan sewa nya, dimana petani memilih komoditas kopi untuk ditanami di lahan tersebut. Namun, petani tidak bisa hanya mengandalkan komoditas kopi untuk memenuhi kebutuhan hidupnya sehari-hari karena kopi hanya dipanen dalam waktu satu tahun sekali sedangkan petani harus terus memenuhi kebutuhan hidupnya. Maka dari itu, petani Kelompok Tani Palintang Jaya juga menanam komoditas lain di lahan sewa tersebut seperti menanam kentang, pisang, kubis, brokoli, dan sawi dimana kentang merupakan komoditas utama yang dibudidayakan oleh petani.

Biaya sewa lahan Perhutani dilakukan dengan sistem bagi hasil yakni $70 \%$ untuk petani dan 30\% untuk pihak perhutani. Luas lahan disewa oleh petani dari pihak perhutani rata-rata sebesar 0,5 1,5 Ha, dimana jarak lahan budidaya kentang cukup jauh. Jauhnya jarak lahan berdampak pada tingginya biaya transportasi yang dikeluarkan oleh petani.

Hasil panen kentang yang dikemas dalam karung dan diangkut dengan 
menggunakan kendaraan bermotor menyebabkan kentang mengalami penurunan kualitas yang akhirnya berdampak pada penurunan harga jual kentang dan berpengaruh terhadap jumlah pendapatan yang diterima oleh petani.

Permasalahan tersebut yang membuat Kelompok Tani Palintang Jaya mengalami kesulitan dalam mengembangkan usahatani kentang baik karena alasan internal maupun eksternal. Faktor kuantitas, kualitas, dan kontinuitas pasokan menjadi salah satu persyaratan yang harus dipenuhi oleh Kelompok Tani Palintang Jaya dalam mengembangkan usahatani kentang, terutama untuk memenuhi permintaan konsumen akan kentang. Oleh karena itu, diperlukan upaya untuk meningkatkan produksi, produktivitas, kualitas dan kontinuitas kentang di Kelompok Tani Palintang Jaya, melalui strategi pengembangan usahatani kentang.

\section{METODE PENELITIAN}

Desain penelitian yang digunakan adalah kualitatif, dengan teknik penelitian yang dilakukan adalah studi kasus (case study).

Pengambilan sampel dilakukan dengan metode Purposive Sampling. Metode Purposive Sampling merupakan teknik penetuan sampel dengan dasar pertimbangan-pertimbangan tertentu di dalam pengambilan sampelnya atau penentuan sampel untuk tujuan tertentu (Sugioyono, 2011). Penentuan sampel dengan menggunakan metode Purposive Sampling mencakup informan utama dan responden petani yang tergabung dalam Kelompok Tani Palintang Jaya. Pengumpulan data dilakukan dengan wawancara, observasi, dokumentasi dan studi literatur.

Biaya adalah semua nilai faktor produksi yang dipergunakan untuk menghasilkan suatu produk dalam suatu periode produksi tertentu (Suratiyah, 2015). Biaya usahatani dapat dibedakan menjadi dua macam yaitu biaya tetap (fixed cost) dan biaya tidak tetap (variable cost). Penerimaan usahatani adalah nilai semua produk yang dihasilkan dari suatu usahatani dalam satu periode tertentu satu musim tanam (MT) atau dalam satuan tahun kegiatan usaha.

a. Biaya usahatani (C) lebih besar daripada penerimaan (revenue, $\mathrm{R}$ ), maka usahatani tersebut rugi

b. Penerimaan lebih besar daripada biaya usahatani $(\mathrm{R}>\mathrm{C})$, maka usahatani tersebut disebut untung

c. Biaya usahatani sama dengan penerimaan usahatani $(\mathrm{R}=\mathrm{C})$, maka 
usahatani tersebut dikatakan tidak untung tidak rugi atau keadaan titik impas (break even point)

d. Jika penerimaan sama dengan nol, usahatani tersebut gagal (puso) dengan asumsi bahwa biaya tidak sama dengan nol, sebab jika biaya $(\mathrm{B}=0)$ artinya tidak ada kegiatan produksi. Selisih antara penerimaan $(\mathrm{P})$ dengan biaya (B) disebut keuntungan (profit).

Pendapatan merupakan selisih dari penerimaan dengan biaya yang dikeluarkan. Besarnya pendapatan usahatani dapat digunakan untuk menilai keberhasilan petani dalam mengelola usahataninya.

David (2009) menyatakan bahwa proses penyusunan perencanaan strategis dilakukan melalui 3 tahap kerangka formulasi strategis, yaitu tahap pengumpulan data (input stage), tahap analisis (matching stage) dan tahap penetapan strategi/ pengambilan keputusan (decision stage).

1. Tahap Pengumpulan Input (Input Stage) merupakan tahap kegiatan pengumpulan data yang meliputi pengklasifikasikan dan pra analisis, dimana data yang didapatkan terdiri atas dua bagian, yaitu data internal dan eksternal. Tahap input pada kerangka kerja perumusan strategi terdiri atas matriks IFE dan matriks EFE.

2. Tahap Pencocokan (Matching Stage) Berdasarkan data dan informasi yang telah didapatkan tahap selanjutnya yaitu memanfaatkan semua informasi tersebut dalam model-model kuantitatif perumusan strategi dengan menggabungkan faktor eksternal dan internal yang berpengaruh terhadap kelangsugan perusahaan. Tahapan ini mencakup matriks SWOT dan matriks IE. Alat analisis tersebut sangat bergantung pada informasi yang diperoleh dari tahap input untuk memadukan peluang dan ancaman eksternal dengan kekuatan dan kelemahan internal.

3. Tahap Keputusan (Decision Stage) dilakukan dengan menghitung rumusan kombinasi strategi matriks SWOT yang didapatkan dari hasil analisis matriks IFE dan matriks EFE. Alat analisis tersebut menggunakan input dari data yang telah diperoleh pada tahapan input untuk mengevaluasi secara objektif strategi-strategi pada tahapan pencocokan yang dapat diimplementasikan. 


\section{HASIL DAN PEMBAHASAN}

\section{Keadaan Umum Lokasi Penelitian}

Kelompok Tani Palintang Jaya berada di Desa Cipanjalu, Kecamatan Cilengkrang Kabupaten Bandung. Desa Cipanjalu memiliki luas wilayah sebesar 2.018,463 Ha. Desa Cipanjalu terletak di ketinggian 800-1400 mdpl dan memiliki tofografi sebagian besar bergelombang serta berbukit dengan tingkat kemiringan lahan berkisar antara $5 \%$ sampai dengan $45 \%$, curah hujan rata-rata $>100$ $\mathrm{mm} /$ bulan dan rata-rata 10 bulan basah/tahun, jenis tanah latosol dengan $\mathrm{pH}$ berkisar antara 5 sampai 7 dan suhu rata rata di Desa Cipanjalu berkisar antara $20^{\circ} \mathrm{C}$ sampai $30^{\circ} \mathrm{C}$ (Tim Penyusun Program Desa Cipanjalu, 2018).

Penerimaan, Biaya, Pendapatan, dan Keuntungan petani dalam usahatani bibit kentang

Penerimaan yang didapatkan petani dalam satu musim tanam (3 bulan) dari dua green house dengan luas $70 \mathrm{~m}^{2}$ adalah sebesar Rp 6.400.000 yang dihasilkan dari penjualan bibit kentang sebanyak 4.000 pohon bibit kentang per musim tanam. Hasil bibit kentang tersebut $80 \%$ untuk petani anggota dan 20\% untuk petani bukan anggota. Harga jual bibit untuk petani anggota yaitu Rp 1.500/pohon dan untuk petani bukan anggota $\mathrm{Rp}$ 2.000/pohon.

Total biaya yang dikeluarkan petani dalam usahatani bibit kentang adalah sebesar $\quad \mathrm{Rp}$ 3.254.857, dengan pengeluaran terbesar adalah untuk biaya penyusutan alat-alat pertanian berupa penyusutan green house yaitu $\mathrm{Rp}$ 1.362.857 dan biaya pembelian arang sekam sebagai media tanam bibit kentang yaitu Rp 780.000. Sedangkan pendapatan total yang diterima oleh petani adalah $\mathrm{Rp}$ 3.145.143.

Tabel 1. Rata-Rata Pendapatan Usahatani Bibit Kentang per $70 \mathrm{~m}^{2}$ per musim tanam di Kelompok Tani Palintang Jaya

\begin{tabular}{lc}
\hline \multicolumn{1}{c}{ Uraian } & $\begin{array}{c}\text { Jumlah } \\
(\mathbf{R p})\end{array}$ \\
\hline Penerimaan & \\
Penjualaan bibit stek & \\
bibit stek untuk anggota & 4.800 .000 \\
bibit stek untuk bukan anggota & 1.600 .000 \\
\hline Total penerimaan & $\mathbf{6 . 4 0 0 . 0 0 0}$ \\
\hline Biaya usahatani & \\
B.1.Biaya Tunai : & \\
1. Planlet kultur jaringan & 140.000 \\
2. Arang sekam & 780.000 \\
3. Larutan AB-MIX & 360.000 \\
4. Root up (perangsang akar) & 222.000 \\
5. Biaya listrik & 390.000 \\
\hline Total Biaya Tunai & $\mathbf{1 . 8 9 2 . 0 0 0}$ \\
\hline B.2. Biaya Diperhitungkan & \\
Penyusutan alat & $\mathbf{1 . 3 6 2 . 8 5 7}$ \\
\hline Total Biaya yang diperhitungkan & $\mathbf{1 . 3 6 2 . 8 5 7}$ \\
\hline Total biaya usahatani & $\mathbf{3 . 2 5 4 . 8 5 7}$ \\
Pendapatan atas biaya tunai & $\mathbf{4 . 5 0 8 . 0 0 0}$ \\
Pendapatan atas biaya total & $\mathbf{3 . 1 4 5 . 1 4 3}$ \\
R/C rasio atas biaya tunai & $\mathbf{3 , 3 8}$ \\
R/C rasio atas biaya total & $\mathbf{1 , 9 7}$ \\
B/C rasio atas biaya tunai & $\mathbf{2 , 4}$ \\
B/C rasio atas biaya total & $\mathbf{1 , 0}$ \\
\hline
\end{tabular}

Sumber : Analisis data primer, 2018 
Hasil analisis $\mathrm{R} / \mathrm{C}$ menunjukkan bahwa penerimaan yang diperoleh petani lebih besar dibandingkan dengan biaya yang dikeluarkan. Nilai R/C atas biaya total adalah 1,97. Hal ini menunjukkan bahwa usahatani kentang di Kelompok Tani Palintang Jaya layak untuk diusahakan.

Sedangkan $\mathrm{B} / \mathrm{C}$ ratio atas biaya total adalah sebesar 1,0. Hal ini menunjukkan bahwa usahtani kentang di Kelompok Tani Palintang Jaya dapat memberikan keuntungan bagi petani.

Penerimaan, Biaya, Pendapatan, dan Keuntungan petani dalam usahatani kentang konsumsi

Rata-rata produksi kentang per hektar yang petani hasilkan dari menanam bibit kentang sebanyak $1.400 \mathrm{~kg}$ adalah $24.000 \mathrm{~kg}$ kentang, dimana dari hasil tersebut $30 \%$, digunakan petani sebagai bibit kentang untuk petani tanam dimusim tanam selanjutnya sehingga kentang yang petani jual sebanyak $16.800 \mathrm{~kg}$. Harga jual kentang sebesar Rp 7.000/kg, sehingga total penerimaan yang diperoleh petani dari produksi kentang per musim tanam adalah Rp 117.600.000 per hektar.

Total biaya yang dikeluarkan oleh petani dalam satu kali musim tanam kentang adalah sebesar Rp 92.874.917 per hektar dengan pengeluaran terbesar yang dikeluarkan oleh petani dalam usahatani kentang adalah untuk biaya pembelian bibit kentang yaitu Rp 54.250.000 per hektar dan biaya untuk membayar upah tenaga kerja yaitu $\mathrm{Rp}$ 18.700.000. Besarnya biaya yang dikeluarkan petani untuk tenaga kerja dikarenakan dalam usahatani kentang dibutuhkan banyak tenaga kerja terutama dalam proses pemeliharaan yang meliputi pembumbunan, pemupukan susulan, penyiangan dan pemberantasan hama dan penyakit serta dalam proses pemanenan kentang.

Sedangkan pendapatan total yang diterima oleh petani adalah $\mathrm{Rp}$ 24.752.083. Berdasarkan hasil analisis $\mathrm{R} / \mathrm{C}$ ratio menunjukkan bahwa penerimaan yang diperoleh petani lebih besar dibandingkan dengan biaya yang dikeluarkan dalam usahatani. Nilai R/C ratio atas biaya total adalah sebesar 1,27. Hal ini menunjukkan bahwa usahatani kentang di Kelompok Tani Palintang Jaya layak untuk diusahakan. Sedangkan B/C ratio atas biaya total adalah sebesar 0,27. Hal ini menunjukkan bahwa usahtani kentang di Kelompok Tani Palintang Jaya dapat memberikan keuntungan bagi petani. 
Tabel 2. Rata-Rata Pendapatan Usahatani Kentang Konsumsi per Hektar per Musim Tanam di Kelompok Tani Palintang Jaya

\begin{tabular}{cc}
\hline Uraian & $\begin{array}{c}\text { Jumlah } \\
\text { (Rp) }\end{array}$ \\
\hline
\end{tabular}

Penerimaan

Kentang

Bibit Kentang 30\%

Kentang konsumsi 117.600 .000

Biaya Usahatani

B.1 Biaya Tunai

1. Bibit :

A. Bibit Grade B

6.300 .000

B. Bibit Grade C

7.350 .000

C. Bibit Grade DN/SS

28.000 .000

D. Bibit Grade TO

12.600 .000

2. Pupuk :
A. Pupuk Kandang
3.600 .000
B. Phonska
805.000
C. TSP
600.000
D. KCL
585.000
E. ZA/Urea

3. Pestisida
A. Fungisida
B. Insektisida
4. Tenaga Kerja :
Wanita

4.176.000

2.100 .000
A. Persiapan Lahan
0
B. Penanaman Bibit
700.000
C. Pemeliharaan
2.800 .000
D. Pemanenan
3.500 .000

Pria

\begin{tabular}{lc} 
A. Persiapan Lahan & 2.700 .000 \\
B. Penanaman Bibit & 900.000 \\
C. Pemeliharaan & 3.600 .000 \\
D. Pemanenan & 4.500 .000 \\
5. Biaya Transportasi & 6.000 .000 \\
\hline Total Biaya Tunai & $\mathbf{9 1 . 1 3 8 . 0 0 0}$ \\
\hline
\end{tabular}

\begin{tabular}{lc}
\hline B.2 Biaya Diperhitungkan : & \\
1. Sewa Lahan & 280.000 \\
2. Biaya Penyusutan & 1.429 .917 \\
\hline Total Biaya Diperhitungkan & $\mathbf{1 . 7 0 9 . 9 1 7}$ \\
\hline Total biaya usahatani & $\mathbf{9 2 . 8 4 7 . 9 1 7}$ \\
Pendapatan atas biaya tunai & $\mathbf{2 6 . 4 6 2 . 0 0 0}$ \\
Pendapatan atas biaya Total & $\mathbf{2 4 . 7 5 2 . 0 8 3}$ \\
R/C atas biaya tunai & $\mathbf{1 , 2 9}$ \\
R/C atas biaya total & $\mathbf{1 , 2 7}$ \\
B/C rasio atas biaya tunai & $\mathbf{0 , 2 9}$ \\
B/C rasio atas biaya total & $\mathbf{0 , 2 7}$ \\
\hline Sumber : Analisis data primer, 2018
\end{tabular}

Strategi Pengembangan Kentang (Solanum tuberosum L.) di Kelompok Tani Palintang Jaya

Matriks IFE dalam analisis SWOT digunakan untuk mengidentifikasi serta mengevaluasi faktor internal di Kelompok Tani Palintang Jaya, yang meliputi kekuatan serta kelemahan yang dimiliki oleh kelompok tani tersebut.

Matriks EFE dalam analisis SWOT digunakan untuk mengidentifikasi serta mengevaluasi faktor eksternal di Kelompok Tani Palintang Jaya, yang meliputi peluang serta ancaman yang dimiliki oleh kelompok tani tersebut. Berikut adalah matriks Internal Factor Evaluation dan matriks External Factor Evaluation. 
Tabel 3. Matriks IFE Kelompok Tani Palintang Jaya

\begin{tabular}{|c|c|c|c|}
\hline Faktor-Faktor Strategis Internal & $\begin{array}{c}\text { Bobot } \\
\text { Rata-rata }\end{array}$ & $\begin{array}{c}\text { Rating } \\
\text { Rata-rata }\end{array}$ & $\begin{array}{c}\text { Skor rata-rata } \\
\text { tertimbang }\end{array}$ \\
\hline \multicolumn{4}{|l|}{ KEKUATAN } \\
\hline $\begin{array}{l}\text { 1. Minat anggota kelompok tani yang tinggi untuk } \\
\text { mengembangkan usahatani kentang }\end{array}$ & 0,072 & 3,3 & 0,238 \\
\hline $\begin{array}{l}\text { 2. Keinginan petani untuk selalu maju dan saling belajar } \\
\text { antar petani }\end{array}$ & 0,072 & 3,4 & 0,245 \\
\hline $\begin{array}{l}\text { 3. Terjalin komunikasi yang baik antara pengurus } \\
\text { dengan seluruh anggota dan rasa kekeluarga yang } \\
\text { tinggi }\end{array}$ & 0,064 & 3,3 & 0,211 \\
\hline $\begin{array}{l}\text { 4. Ketua dan pengurus kelompok tani yang saling } \\
\text { bekerjasama dengan anggota untuk mengembangkan } \\
\text { usahatani kentang }\end{array}$ & 0,071 & 3,3 & 0,234 \\
\hline $\begin{array}{l}\text { 5. Sudah mulai melakukan pembibitan kentang sehingga } \\
\text { tidak ketergantungan bibit dari daerah lain }\end{array}$ & 0,064 & 3,6 & 0,230 \\
\hline $\begin{array}{l}\text { 6. Kentang yang dihasilkan memiliki warna kulit cerah } \\
\text { dan mulus }\end{array}$ & 0,065 & 3,7 & 0,241 \\
\hline 7. Memiliki tujuan pasar yang jelas & 0,079 & 2,9 & 0,229 \\
\hline 8. Memiliki uang kas kelompok & 0,076 & 2,7 & 0,205 \\
\hline Jumlah & 0,563 & & 1,833 \\
\hline \multicolumn{4}{|l|}{ KELEMAHAN } \\
\hline $\begin{array}{l}\text { 1. Belum bisa memenuhi permintaan bibit kentang untuk } \\
\text { di luar daerah Desa Cipanjalu }\end{array}$ & 0,087 & 1,8 & 0,157 \\
\hline $\begin{array}{l}\text { 2. Kurangnya kemampuan petani dalam melakukan } \\
\text { penyotiran kentang }\end{array}$ & 0,073 & 1,8 & 0,131 \\
\hline $\begin{array}{l}\text { 3. Kurangnya ketersediaan sarana dan prasarana dalam } \\
\text { mengembangkan usahatani bibit kentang }\end{array}$ & 0,061 & 1,8 & 0,110 \\
\hline 4. Biaya tenaga kerja tinggi & 0,078 & 1,2 & 0,094 \\
\hline 5. Penurunan kualitas kentang akibat sistem distribusi & 0,075 & 1,6 & 0,120 \\
\hline 6. Modal yang masih terbatas & 0,063 & 1,5 & 0,095 \\
\hline Jumlah & 0,437 & & 0,706 \\
\hline Total & $\mathbf{1 , 0 0 0}$ & & 2,539 \\
\hline
\end{tabular}

Sumber: Analisis data primer, 2018

Matriks IFE menunjukkan bahwa kekuatan yang utama bagi Kelompok Tani Palintang Jaya adalah keinginan petani untuk selalu maju dan saling belajar antar petani dengan nilai tertimbang 0,245. Kelemahan utama bagi Kelompok Tani Palintang Jaya ditunjukkan oleh nilai tertimbang terkecil diantara faktor kelemahan yang ada, yaitu biaya tenaga kerja tinggi dengan nilai tertimbang 0,094.
Berdasarkan Tabel 3. hasil analisis matriks IFE menunjukkan total nilai tertimbang yang dimiliki Kelompok Tani Palintang Jaya adalah sebesar 2,539. Total nilai tertimbang tersebut merupakan nilai yang termasuk dalam kategori rata-rata. Hal ini mengindikasikan bahwa kemampuan kelompok tani tersebut saat ini dalam memanfaatkan kekuatan dan meminimalkan kelemahan yang ada masih rata-rata. 
Tabel 4. Matriks EFE Kelompok Tani Palintang Jaya

Faktor-faktor Strategis Eksternal

\section{Bobot Rating Skor rata-rata \\ Rata-rata Rata-rata tertimbang}

\section{PELUANG}

1. Lingkungan yang cocok untuk budidaya kentang

2. Meningkatnya kesadaran masyarakat dalam memenuhi kebutuhan gizi bagi kesehatan

$\begin{array}{lll}0,069 & 3,3 & 0,228 \\ 0,094 & 2,3 & 0,216 \\ 0,097 & 2,4 & 0,233\end{array}$
berdampak pada peningkatan konsumsi kentang bagi masyarakat

4. Adanya hubungan yang baik antara kelompok tani palitang jaya dengan BBPP-Lembang serta dinas pertanian setempat

5. Sering diadakan pelatihan-pelatihan untuk Kelompok Tani Palintang Jaya

6. Penggunaan budidaya bibit kentang dengan teknik stek

7. Perkembangan teknologi yang pesat

$0,068 \quad 3,3 \quad 0,224$

8. Banyak terjadi pemalsuan bibit oleh oknum supplier bibit

\begin{tabular}{llll}
\multicolumn{1}{c}{ Jumlah } & $\mathbf{0 , 6 6 3}$ & & $\mathbf{1 , 8 6 4}$ \\
\hline ANCAMAN & & & \\
1. Serangan hama dan penyakit & 0,075 & 1,8 & 0,135 \\
2. Cuaca yang tidak menentu dan iklim yang berubah- & 0,087 & 2,0 & 0,174 \\
$\quad$ ubah & 0,074 & 2,0 & 0,148 \\
3. Perubahan harga input produksi & 0,101 & 2,8 & 0,283 \\
4. Pesaing daerah lain lebih unggul & $\mathbf{0 , 7 4 0}$ \\
\hline \multicolumn{1}{c}{ Total } & $\mathbf{0 , 3 3 7}$ & $\mathbf{2 , 6 0 4}$
\end{tabular}

Sumber : Analisis data primer, 2018

Matriks EFE menunjukkan bahwa peluang utama yang paling potensial untuk Kelompok Tani Palintang Jaya adalah banyak terjadi pemalsuan bibit oleh oknum supplier bibit dengan nilai tertimbang sebesar 0,266. Ancaman utama yang paling berpengaruh bagi kelompok tani adalah serangan hama dan penyakit dengan nilai tertimbang sebesar 0,135 .

Tabel 4 memperlihatkan hasil analisis Matriks EFE Kelompok Tani Palintang Jaya adalah sebesar 2,604. Hal ini mengindikasikan bahwa kemampuan kelompok tani dalam merespon peluang dan ancaman yang ada masih rata-rata, dengan kata lain, kelompok tani tersebut mampu mengambil keuntungan dari peluang yang ada dan dapat meminimalkan pengaruh yang mungkin ditimbulkan dari ancaman eksternal.

Berdasarkan hasil analisis matriks IFE diperoleh total skor tertimbang sebesar 2,539 dan total skor tertimbang matriks EFE sebesar 2,604. Jika masingmasing total skor IFE dan EFE dipetakan dalam mariks IE maka posisi kelompok tani saat ini berada pada daerah V yaitu kelompok tani berada pada kondisi hold and maintain atau menjaga dan mempertahankan. Pada posisi ini strategi 
yang dapat dilakukan adalah penetrasi pasar dan pengembangan produk. Dengan ini artinya kelompok tani harus melakukan perluasan pasar yang didukung dengan kekuatan dan peluang yang dimiliki oleh kelompok tani. Strategi penetrasi pasar yaitu usaha untuk mendalami pasar yang ada dengan tujuan untuk peningkatan pasar suatu produk atau jasa yang sudah ada di pasar melalui usaha pemberian pelayanan yang baik (Wulandari, 2009). Strategi yang dihasilkan pada matriks IE hanya menghasilkan strategi alternatif secara umum tanpa adanya implementasi yang lebih teknis pada kelompok tani. Oleh karena itu, matriks IE harus dilengkapi dalam matriks SWOT yang memberikan rincian lebih jelas mengenai alternatif strategi yang tepat untuk dilakukan oleh kelompok tani (Gambar 1).

\section{SKOR BOBOT TOTAL IFE}

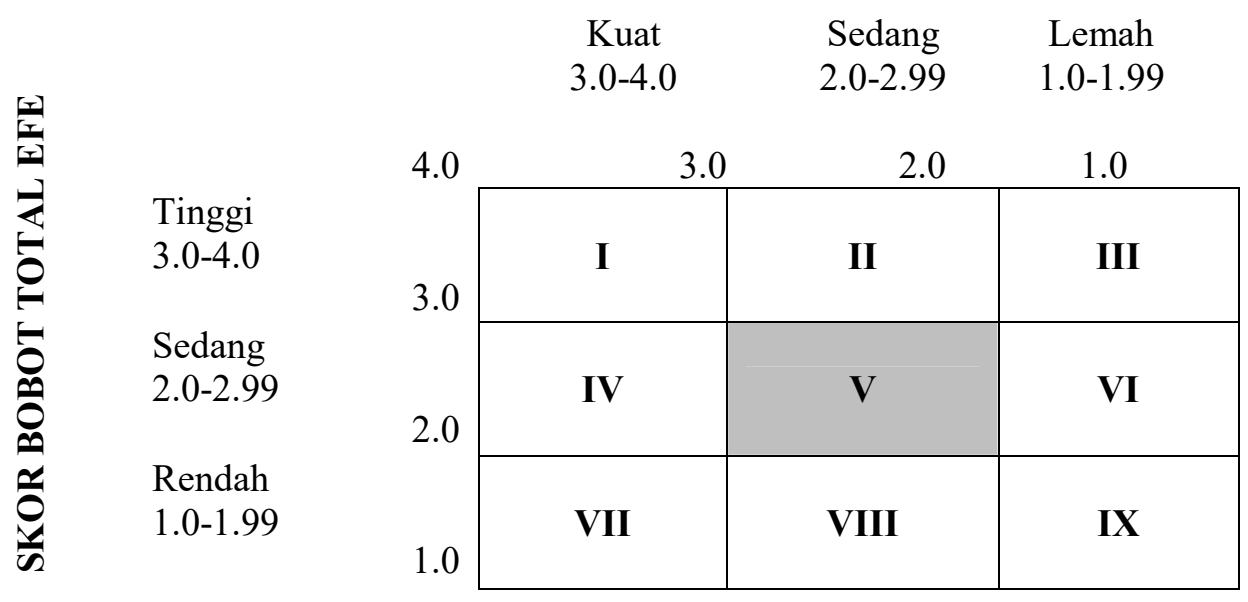

Gambar 1. Matriks Internal-Eksternal Kelompok Tani Palintang Jaya

Penerapan analisis matriks SWOT dapat dilakukan dengan cara membandingkan secara sistematik antara faktor eksternal peluang (opportunities) dan ancaman (threats) dengan faktor internal kekuatan (strengths) dan kelemahan (weaknesses). Hal ini bertujuan untuk dapat mengidentifikasi dan mengenali satu dari empat kategori yang sesuai dengan situasi lingkungan internal dan eksternal kelompok tani. Alat analisis SWOT disusun dari hasil matriks IFE dan matriks EFE yang terdiri dari strategi S-O (Strengths-Opportunities), strategi S-T (Strenghts-Threats), strategi W-O (Weaknesses-Opportunities), dan strategi W-T (Weaknesses-Threats).

Berdasarkan hasil pemetaan data matrik internal dan ekternal yang di aplikasikan ke dalam Diagram Cartesius (Gambar 2.), Kelompok Tani Palintang Jaya berada pada kuadran 1 (Growth 
Agresif) yang menunjukkan bahwa kelompok tani tersebut berada pada situasi yang menguntungkan dimana kelompok tani tersebut memiliki peluang dan kekuatan sehingga dapat memanfaatkan peluang yang ada. Hal tersebut membuat kelompok tani harus lebih bersikap agresif atau lebih aktif lagi.

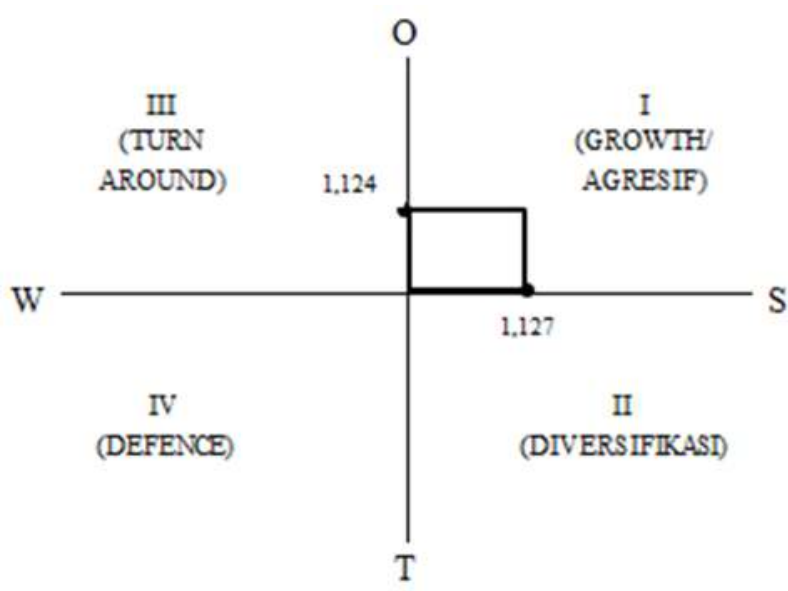

\section{Gambar 2. Diagram Cartesius Kelompok Tani} Palintang Jaya

Berdasarkan matriks SWOT maka didapatkan 6 alternatif strategi pengembangan yang meliputi Strategi S$\mathrm{O}$, strategi S-T, strategi W-O dan strategi W-T. Alternatif strategi S-O diantaranya adalah: (1) meningkatkan kemampuan anggota dalam budidaya bibit kentang. Alternatif strategi S-T meliputi (2) meningkatkan kualitas kentang yang dihasilkan petani, dan (3) meningkatkan pengembangan budidaya bibit kentang. Alternatif strategi W-O meliputi (4) memanfaatkan pelatihan-pelatihan yang sering diikuti oleh kelompok tani, dan (5) mencari alternatif perolehan sumber modal untuk pengembangan usaha. Alternatif strategi W-T diantaranya adalah (6) mengelola usahatani kentang dan bibit kentang lebih optimal agar pendapatan yang diperoleh meningkat sehingga ada dana tambahan untuk mengatasi perubahan harga input produksi.

Berdasarkan analisis pada kuadran matriks SWOT dengan pendekatan kuantitatif diketahui bahwa posisi strategi dalam pengembangan budidaya kentang di Kelompok Tani Palintang Jaya berada pada kuadran 1, sehingga dalam matriks SWOT pendekatan strategi yang dirumuskan adalah strategi SO.

Strategi S-O bagi kelompok tani dari hasil pencocokan analisis matrik SWOT serta matriks IFE dan EFE adalah sebagai berikut:

Meningkatkan kemampuan anggota dalam budidaya bibit kentang. Strategi yang dapat dilakukan oleh Kelompok Tani Palintang Jaya adalah meningkatkan kemampuan anggota dalam budidaya bibit kentang. Hal ini didasari atas tingginya minat dan keinginan petani untuk mengembangkan usahatani kentang dengan sikap petani yang selalu ingin belajar, sehingga perlu disesuaikan dengan peningkatan kemampuan anggota mengenai budidaya kentang terutama saat 
ini kelompok tani tersebut sudah melakukan pembibitan kentang sehingga tidak ketergantungan bibit dari daerah lain.

Strategi yang dilakukan untuk dapat meningkatkan kemampuan budidaya bibit kentang anggota Kelompok Tani Palintang Jaya yakni dengan mengikutsertakan kembali anggota pada pelatihan yang diadakan oleh BBPPLembang serta dinas pertanian setempat atau dengan memberikan sosialisasi mengenai budidaya bibit kentang oleh pengurus kelompok tani terutama bagi petani-petani yang sebelumnya tidak pernah mengikuti pelatihan-pelatihan tersebut dan tidak mengetahui bagaimana proses melakukan pembibitan kentang.

Hubungan yang baik antara Kelompok Tani dengan BBPP-Lembang serta dinas pertanian setempat, dapat dimanfaatkan oleh kelompok tani untuk dapat membantu petani dalam mengembangkan usahatani bibit kentang. Peningkatan kemampuan petani diperlukan agar budidaya bibit kentang yang dilakukan petani dapat berhasil dan sesuai dengan harapan, sehingga petani dapat memperoleh tambahan pendapatan serta dapat mencapai tujuan kelompok tani untuk menjadi sentra produksi bibit kentang di Jawa Barat.

\section{KESIMPULAN DAN SARAN}

\section{Kesimpulan}

Berdasarkan hasil pembahasan dari penelitian yang telah dilakukan sebelumnya, maka dapat diambil kesimpulan sebagai berikut:

1. Hasil analisis pendapatan usahatani menunjukkan bahwa pendapatan petani dalam usahatani bibit kentang per musim tanam adalah Rp 3.145.143 Sedangkan pendapatan petani dalam usahatani kentang konsumsi per musim tanam sebesar $\mathrm{Rp} 24.752 .083$ per hektar. Hal ini menunjukkan bahwa usahatani bibit kentang dan usahatani kentang konsumsi dapat dikatakan menguntungkan untuk dijalankan.

2. Faktor internal yang menjadi kekuatan utama bagi Kelompok Tani Palintang Jaya dalam mengembangkan usahatani kentang adalah keinginan petani untuk selalu maju dan saling belajar antar petani dan kelemahan utama bagi Kelompok Tani Palintang adalah biaya tenaga kerja tinggi.

3. Faktor eksternal yang menjadi peluang bagi Kelompok Tani Palintang Jaya dalam mengembangkan usahatani kentang adalah banyak terjadi pemalsuan bibit oleh oknum supplier bibit dan ancaman utama yang paling 
berpengaruh bagi kelompok tani adalah serangan hama dan penyakit.

4. Hasil analisis perhitungan kombinasi strategi matriks SWOT menunjukkan bahwa prioritas strategi utama yang harus dilakukan oleh Kelompok Tani Palintang Jaya adalah meningkatkan kemampuan anggota dalam budidaya bibit kentang.

\section{Saran}

Berdasarkan hasil analisis pendapatan usahatani dan faktor internal dan eksternal, terdapat beberapa saran yang dapat penulis berikan, yaitu:

1. Usahatani kentang Kelompok Tani Palintang Jaya harus terus dikembangkan terutama dalam pengembangan usahatani pembibitan kentang, dimana langkah awal yang sebaiknya Kelompok Tani Palintang Jaya lakukan yaitu meningkatkan kemampuan anggota kelompok tani dalam budidaya bibit kentang.

2. Kelompok Tani Palintang Jaya dapat mengimplementasikan strategi yang telah dirumuskan sesuai dengan kondisi yang ada kelompok tani. Selain itu sebaiknya dalam menjalankan kegiatan usahatani kentang, Kelompok Tani Palintang Jaya dapat mengidentifikasi ancaman yang berasal dari pesaing sehingga kelompok tani dapat memanfaatkan kekuatan dan peluang yang mereka miliki.

\section{DAFTAR PUSTAKA}

Badan Pusat Statistik. 2017. Povinsi Jawa Barat Dalam Angka 2016. Jawa Barat.

David Fred R. 2009. Manajemen Strategis: Konsep, Edisi Keduabelas. Salemba Empat: Jakarta.

Purwanto, M. J., Harisudin, M., dan Qonita, A. 2016. Strategi Pengembangan Budidaya Kentang (Solanum Tuberosum L) Di Kecamatan Ngablak Kabupaten Magelang. Sepa: Vol.13 No.1: 5362. ISSN: 1829-9946.

Rangkuti Freddy. 2006. Analisis SWOT: Teknik Membedah Kasus Bisnis. Jakarta: Gramedia Pustaka Utama.

Samandi Budi. 2007. Kentang dan Analisis Usaha Tani. Yogyakarta: Kanisius. ISBN : 978-979-21-14614 . 1997. Usaha Tani Kentang. Yogyakarta: Kanisius.

Setiadi dan Nurulhuda Surya Fitri. 2003. Kentang ( Varietas dan Pembudidayaan ). Jakarta: Penebar Swadaya. ISBN : 979-489-169-X

Setiadi. 2009. Budidaya Kentang. Jakrta: Swadaya. ISBN 979-002-383-9

Sugiyono.2012.Metode Penelitian Kuantitatif Kualitatif dan R\&D. Bandung: Alvabeta, CV.

Suratiyah Ken. 2015. Ilmu Usahatani edisi revisi. Jakarta : Penebar Swadaya.

Tim Penyusun Program Desa Cipanjalu. 2018. Data Potensi Desa Cipanjalu tahun 2017.

Wulandari Sekar Nur. 2009. Pendapatan Usahatani Dan Pengembangan Usaha Tanaman Hias Daun Potong Di Bogor, Jawa Barat (Kasus Pada PT Pesona Daun Mas Asri Dan Kelompok Tani Al-Busyro Florist. 
Jurnal Ilmiah Mahasiswa AGROINFO GALUH

Volume 6, Nomor 1, Januari 2019: 80-94

Skripsi. Departemen Ilmu Sosial

Ekonomi Fakultas Ekonomi dan

Manajemen Institut Pertanian

Bogor: Bogor 